Vol u m e $14 \mathrm{Num}$ be $1 \mathrm{P}$ a ge s 26-34, 2020

\title{
ANALISIS PENGARUH ENTREPRENEURIAL MOTIVATION TERHADAP KEPUTUSAN MENJADI SEORANG WIRAUSAHA
}

\author{
Fransisca Desiana Pranatasari
}

Universitas Sanata Dharma, Indonesia

INFO ARTIKEL

DOI:10.32812/jibeka.v14i1.138

ISSN-P: 0126-1258

ISSN-E: 2620-875X

Keywords: Entrepreneurship, Entrepreneurial Motivation, Entrepreneur

\begin{abstract}
Since 2015, Indonesia has declared itself to be active in the era of the ASEAN conomic Community (AEC). This decision sparked changes that exist in our society. However, Are we ready for this change? In the framework of an active role in this MEA, Dinas Perindustrian dan Perdagangan began concentrate building entrepreneurs who are active in the nation's economy. Disperindag, educational institutions, and many other agencies focus on providing support in the form of training to build entrepreneurial attitude motivation to become entrepreneurs. The purpose of this study was to consideration of the agencies in the training process after foster the spirit become entrepreneurs. This study uses a quantitative approach to the instrument questionnaires and multiple regression analysis as a tool of analysis. Methodof sample collection is done by purposive sampling method to the 50 CEOs start up business. The results of this study presented is a deciding factor entrepreneurial motivation influence a person's decision to become entrepreneurs.
\end{abstract}

\section{ABSTRAK}

Kata Kunci: Kewirausahaan, Motivasi Kewirausahaan, Wirausaha

(c) 2020 Jibeka. All rights reserved

Sejak tahun 2015, negara Indonesia menyatakan untuk aktif dalam era Masyarakat Ekonomi Asean (MEA). Keputusan ini memicu perubahan dalam masyarakat. Namun, siapkah kita dengan perubahan tersebut? Dalam rangka berperan aktif di MEA ini, Dinas Perindustrian dan Perdaganan mulai konsentrasi membangun bibit wirausaha yang aktif dalam perekonomian bangsa. Disperindag, instansi pendidikan, LSM, dan banyak instansi lainya fokus pada pemberian dukungan bentuk pelatihan untuk membangun sikap entrepreneurial motivation menjadi wirausaha. Tujuan penelitian ini adalah untuk pertimbangan instansiinstansi dalam proses pelatihan berikutnya untuk menumbuhkan semangat menjadi wirausaha. Penelitian ini menggunakan pendekatan kuantitatif dengan instrumen kuisioner dan metode regresi berganda sebagai alat analisisnya. Metode pengumpulan sampel dilakukan dengan metode purposive sampling kepada 50 CEO start up business. Hasil dari penelitian ini adalah faktor penentu entrepreneurial motivation berpengaruh terhadap keputusan seseorang menjadi wirausaha. 


\section{Pendahuluan}

Partisipasi Indonesia dalam komunitas ASEAN (Association of Southeast Asian Nations) pada dasarnya sudah dilakukan sejak tahun 1967. Menurut kementrian kesekretariatan negara (2014), terdapat 3 pilar utama yang menjadi fokus pembentukan komunitas ini yaitu keamanan, ekonomi dan sosial budaya. Kerjasama ini diharapkan mampu menjawab permasalahan internasional dan mempererat integrasi negara ASEAN. Pertimbangan tersebut yang memotivasi Indonesia untuk berperan aktif di salah satu pilar yaitu ekonomi dalam bentuk keikutsertaannya dalam era Masyarakat Ekonomi Asean (MEA).

Momen ini akan menimbulkan banyak keuntungan, salah satunya adalah semakin terbukanya lapangan pekerjaan karena perusahaan asing bebas masuk, semakin mudahnya transaksi jual beli dengan pihak asing sehingga memacu majunya kegiatan ekspor, pekerja dari Indonesia juga mampu dengan leluasa menjadi pekerja di negara ASEAN lainnya serta masih banyak lagi. Namun momen ini juga perlu dipersiapkan supaya negara kita tidak kaget dengan perubahan. Perubahan yang sangat cepat akan menuntut sebuah transformasi bisnis yang tepat. Hal ini selaras dengan pendapat Sutanto et al (2008) yaitu Indonesia sekarang sedang mengalami perubahan budaya dominasi atau monopoli menuju pasar bebas.

Tantangan terbesar negara kita terhadap era MEA adalah daya saing Indonesia yang masih relatif lebih rendah dibandingkan dengan negara di Asean terutama Singapura, Malaysia, Brunei Darussalam, dan Thailand.(Majalah Industri edisi 2, 2013). Selain daya saing, jumlah entreprneur di Indonesia masih dibilang cukup rendah dari beberapa negara tetangga di ASEAN. Sangat disayangkan kalau negara kita hanya bisa menjadi negara konsumtif saja. Untuk itu pemerintah, instansi pendidikan, dan beberapa instansi lainnya mempersiapkan masyarakat untuk lebih produktif melalui pelatihan yang memicu masyarakat untuk memiliki entreprneurial motivation menjadi seorang wirausaha. Bank Mandiri merupakan contoh instansi yang aktif dalam menumbuhkan entrepreneurial motivation melalui kompetisi yang difokuskan kepada generasi muda yang kreatif dan berbakat dalam pengembangan ide bisnis. Kompetisi ini secara aktif memberikan pelatihan, workshop, hadiah, pameran, publikasi dan pembinaan bagi peserta kompetisi yang topiknya selalu tentang kewirausahaan dalam rangka membangun entrepreneurial motivation kepada masyarakat agar pilihan karir menjadi wirausaha semakin meningkat.

Dengan tumbuhnya wirausaha, maka perekonomian Indonesia akan semakin aktif. Kementrian koperasi dan UKM (SWA.co.id, 2015) menunjukan bahwa sebesar $0.43 \%$ dari total populasi Indonesia yaitu sebesar 42 juta UKM tercatat serta perlu dilakukan pembinaan. Jumlah ini masih dirasa belum cukup sehingga kita perlu meningkatkan jumlah entrepreneur di Indonesia. Penelitian kali ini peneliti ingin melihat apakah faktor penentu entrepreneurial motivation berpengaruh terhadap keputusan seseorang menjadi wirausaha? Tujuan penelitian ini adalah digunakan untuk pertimbangan instansi-instansi dalam proses pelatihan berikutnya untuk menumbuhkan semangat menjadi wirausaha.

Entrepreneurial motivation merupakan motivasi berwirausaha yang kemudian dipelajari kaitannya terhadap hasil-hasil pribadi seseorang yang mencakup karakter seseorang untuk menjadi wirausaha (Raposo et al, 2008). Lebih lanjut Raposo et al (2008) menjelaskan bahwa katakteristik atau entrepreneurial motivation seorang wirausaha adalah memiliki beberapa atribut individu yang mendukung keputusannya menjadi wirausaha, mampu mengambil risiko, punya keinginan untuk berprestasi, percaya diri, punya motivasi meraih keuntungan, kreatif, dan faktor eksternal lain. Menurut Singh (2011) Seorang wirausaha harus mampu menunjukan karakteristik kewirausahaan mereka yang terbentuk atas motivasi kewirausahaannya yaitu:

1. kualitas bawaan (atribut individu)

2. faktor pribadi dan sosial,

3. hubungan mendapatkan pendapatan dan karir,

4. keterkaitan pasar

5. keterkaitan lingkungan 
Salah satu faktor eksternal yang bisa dipakai untuk membangun motivasi untuk menjadi wirausaha adalah lewat dunia pendidikan. Dalam dunia pendidikan terutama untuk pendidikan entrepreneurship, proses pembelajarannya sebaiknya menggunakan konsep inovasi kurikulum pendidikan yang menitikberatkan pada proses pencipyaan nilai brsama yang menghasilkan hubungan berkelanjutan dalam hal ini adalah pengembangan bisnis terprogram dan bersinergi secara akademik (OBE dan Templeman, 2013).Hasil pembelajarannya adalah sebuah penilaian yang dinilai dan dilihat secara komprehensif terkait dengan ketrampilan, kebiasaan, pengetahuan, dan etika berperilaku.

Dalam ilmu kewirausahaan, terdapat hubungan positif antara kemampuan faktor, instruksi, dan pengalaman yang diwujudkan pada pengusaha dan manajer (Raposo et al, 2008). Davidsson dalam Raposo (2008) menemukan bahwa beberapa penelitian menemukan bahwa terdapat hubungan signifikan beberapa faktor kemampuan berpikir, ketrampilan hubungan manusia, komunikasi dan pengetahuan teknis terhadap keberhasilan seseorang menjadi wirausaha. Lebih lanjut, Singh (2011) menyatakan bahwa kualitas bawaan yang mempengaruhi keputusan seseorang menjadi wirausaha adalah kemampuan mengambil risiko dan tantangan serta jiwa kreatif yang kemudian mendorong sikap kompetitif untuk memulai sebuah bisnis.

Rasa percaya diri dan rasa ingin berpetualang dapat menjadi faktor pribadi yang mendorong seseorang untuk menjadi wirausaha (Singh, 2011). Lebih jauh lagi Singh (2011) menjelaskan bahwa dalam hidup bermasyarakat kebutuhan seseorang tidak hanya terbatas pada kebutuhan dasar, namun juga kebutuhan untuk diakui. Pengakuan dari masyarakat ini yang kemudian menjadi faktor sosial yang mendorong seseorang menjadi wirausaha (Singh, 2011). Pengakuan ini yang akan menambah prestasi dan harga diri seseorang dalam hidup bermasyarakat.

Pada beberapa penelitian empiris, motivasi ekonomi muncul dalam kaitannya dengan tujuan lainnya. Pada dasarnya seseorang selalu terpacu untuk memiliki penghasilan tambahan bagi kebutuhan hidupnya (Raposo, 2008). Pendapatan yang dikumpulkan seseorang pada masa mudanya cenderung dipersiapkan untuk hari tuanya (Singh, 2011). Di sisi lain, banyak orang yang akhirnya memutuskan menjadi wirausaha karena tidak ingin menganggur (Singh, 2011).

Kemudahan memasuki pasar merupakan salah satu kunci keberhasilan sebuah bisnis (Chu, 2011). Mudahya akses masuk pasar dapat memotivasi seseorang untuk menekuni bisnis tertentu sehingga dia akan menjadi seorang entrepreneur (Singh, 2011). Akses ini meliputi akses modal, akses produk, akses pemasok, jaringan atau koneksi dan akses sumber daya (Singh, 2011).

Kebutuhan dan kemandirian seseorang pada beberapa penelitian dijelaskan bahwa terdorong adanya dukungan dari lingkungan (Raposo, 2011). Lingkungan yang kondusif dan keluarga yang mendukung dapat memotivasi seseorang memutuskan menjadi seorang wirausaha (Singh, 2011). Lebih dalamnya lagi bahwa motivasi seseorang menjadi wirausaha dapat dipicu oleh kondisi ekonomi suatu negara (Singh, 2011).

\section{Metode Penelitian}

Umumnya, motivasi berwirausaha yang terbentuk di negara berkembang dipengaruhi oleh kebutuhan dan tekanan dari lingkungan bahkan kemiskinan (Eijdenberg et al, 2015). Situasi ini membuat seseorang merasa bahwa dia harus mencari peluang untuk mengatasinya. Banyak definisi kewirausahaan yang dikemukakan oleh para ahli. Kewirausahaan adalah sebuah proses dimana seseorang mampu memulai bisnis karena pekerjaan lain tidak memuaskan kebutuhannya, definisi ini yang kemudian menjadi salah satu motivasi seseorang akhirnya memutuskan menjadi wirausaha (Eijdenberg et al, 2015). Kebutuhan paling dasar dari manusia adalah makanan dan tempat tinggal. Bila kebutuhan mendasar tersebut tidak mampu dipenuhi maka seseorang akan tidak mampu bertahan hidup. Dengan demikian situasi yang mendesak inilah yang memacu seseorang untuk bertahan hidup dengan mencari peruntungan yang lain. Kebutuhan ini mengacu pada kemampuan untuk mengkontrol situasi dan keinginan untuk menjadi independen (Raposo et al, 2008). Motivasi untuk memulai bekerja secara independen dengan mengambil langkah 
pertama untuk petualangan baru merupakan faktor inisiatif yang biasanya dimiliki oleh seorang wirausaha (Raposo et al, 2008). Keputusan berwirausaha juga untuk meningkatkan pendapatan negara dan menciptakan lapangan kerja bagi mereka sendiri untuk bertahan hidup (Eijdenberg et al, 2015). Motivasi untuk mampu bertahan hidup ini juga menjadi pertimbangan seseorang memutuskan menjadi wirausaha. Motivasi membantu seseorang untuk memahami mengapa individu bertindak dengan cara tertentu dan mendorong untuk proses pengambilan keputusan (Raposoet al, 2008). Loss dan Bascunan (2011) mengatakan bahwa motivasi dapat dikatakan sebagai kebutuhan untuk mencapai sesuatu, pengendalian risiko, punya visi, dan mandiri.

$\mathbf{H}_{1}$ :Kualitas bawaan berpengaruh positif terhadap keputusan seseorang menjadi wirausaha $\mathbf{H}_{2}$ :Faktor pribadi dan sosial berpengaruh positif terhadap keputusan seseorang menjadi wirausaha

$\mathbf{H}_{3}$ :Hubungan pendapatan dan karir berpengaruh positif terhadap keputusan seseorang menjadi wirausaha

$\mathbf{H}_{4}$ :Keterkaitan pasar berpengaruh positif terhadap keputusan seseorang menjadi wirausaha $\mathbf{H}_{5}$ :Keterkaitan lingkungan berpengaruh positif terhadap keputusan seseorang menjadi wirausaha

Penelitian ini menggunakan pendeketan kuantitatifdengan jumlah sampel 50 pemilik start-up business yang berada di Surabaya. Start up business merupakan usaha yang dibangun dengan umur usaha kurang dari 5 tahun (Sutanto, 2008). Teknik probability sampling digunakan peneliti untuk teknik pengambilan sampel dimana peneliti tidak memberi peluang yang sama untuk setiap anggota populasi yang akan dipilih sebagai sampel (Sugiyono, 2013). Kriteria sampel dalam penelitian ini adalah seorang wirausaha, usaha berdiri kurang dari 5 tahun, dan domisili usaha di Surabaya. Keseluruhan penelitian ini menggunakan SPSS 22.0 sebagai media untuk membantu peneliti dalam proses penelitian. Penelitian ini menggunakan data primer sebagai bahan untuk uji ke tahapan berikutnya. Data primer merupakan data yang langsung diperoleh dari sumber data pertama di lokasi penelitian atau objek penelitian (Bungin, 2013). Intrumen penelitian ini menggunakan kuisioner dengan skala likert.

Variabel independen dalam penelitian ini meliputi kualitas bawaan $\left(X_{1}\right)$, faktor pribadi dan sosial $\left(\mathrm{X}_{2}\right)$, hubungan pendapatan dan karir $\left(\mathrm{X}_{3}\right)$, keterkaitan pasar $\left(\mathrm{X}_{4}\right)$, dan keterkaitan lingkungan $\left(X_{5}\right)$. Variabel dependen dalam penelitian ini adalah keputusan menjadi wirausaha (Y). Hal ini disebabkan karena definisi variabel dependen menurut Sugiyono (2013:59) adalah variabel yang dipengaruhi oleh variabel bebas.

Uji validitas dan reabilitas dilakukan peneliti untuk menguji layak atau tidaknya item pertanyaan yang diajukan kepada responden. Validitas adalah tes yang dilakukan untuk melihat apakah instrumen yang dipakai di penelitian dapat mewakili penelitian dengan baik atau tidak (Sekaran dan Bougie, 2011). Reabilitas adalah tes yang dilakukan untuk melihat apakah hasil penelitian sudah konsisten mewakili penelitian atau tidak (Sekaran dan Bougie, 2011). Apabila dikatakan valid dan reliabel, maka penelitian dapat dilanjutkan ketahapan selanjutnya.

Uji validitas dilakukan dengan menggunakan rumus Pearson Product Moment. Dengan bantuan SPSS 22.0 akan didapatkan dimana nilai validitas yang kuat jika koefisien korelasi ( $r$ ) sama atau lebih besar dari 0,119, namun apabila koefisien korelasi ( $r$ ) kurang dari 0,119 maka instrumen tersebut dinyatakan tidak valid. Adapun nilai 0,119 ini dapat diperoleh melalui tabel Pearson Product Moment dengan tingkat kesalahan $(\alpha=0,05)$ dan jumlah sampel yang diambil $(n=50)$.

Instrumen akan dikatakan handal apabila nilai Cronbach's alpha lebih besar atau sama dengan 0,119. Jika Cronbach's alpha lebih kecil dari 0,119 maka butir kuisioner tidak reliabel. Nilai 0,119 diperoleh dari tabel Pearson Product Moment dengan tingkat kesalahan $(\alpha=0,05)$ dan jumlah sampel yang diambil $(n=50)$. Tahap uji asumsi klasik ini bertujuan untuk mengetahui apakah data-data yang digunakan sudah memenuhi syarat-syarat. Adapun uji yang digunakan yaitu uji multikolinearitas, uji heteroskedastisitas, dan uji normalitas data. Teknik analisis data dilakukan dengan teknik regresi berganda dengan model persamaan sebagai berikut: 


$$
Y=a+\beta X_{1}+\beta X_{2}+\beta X_{3}+\beta X_{4}+\beta X_{5}+e
$$

\section{Keterangan:}

$Y$ adalah keputusan menjadi wirausaha

$\mathrm{X}_{1}$ adalah kualitas bawaan

$\mathrm{X}_{2}$ adalah faktor pribadi dan sosial

$\mathrm{X}_{3}$ adalah hubungan pendapatan dan karir

$\mathrm{X}_{4}$ adalah keterkaitan pasar

$X_{5}$ adalah keterkaitan lingkungan

\section{Hasil Penelitian dan Pembahasan}

Pentingnya membangun jiwa entrepreneurship menjadi sesuatu yang tidak akan pernah habis untuk dibahas, baik oleh praktisi, akademisi, maupun pemerintah. Kali ini peneliti ingin berkontribusi dalam membangun jiwa entrepreneurship melalui penelitian ini. Kuisioner yang telah dibagikan ke 50 CEO start up business di Surabaya meliputi $58 \%$ lakilaki dan $42 \%$ perempuan dengan kisaran umur responden adalah 19 tahun - 30 tahun. Data pendidikan terakhir responden didapatkan bahwa lulusan SMA 68\%, lulusan S1 yaitu 25\%, dan lulusan S2 yaitu 7\%. Data demografis berikutnyaadalah bidang bisnis repondenyaitu $37 \%$ bergerak dibidang fashion, sejumlah $16 \%$ bergerak dibidang entertain dan paling banyak yaitu $47 \%$ bergerak dibidang food and beverage.

Selanjutnya peneliti melakukan uji validitas dan reliabilitas untuk melihat apakah intrumen penelitian ini bisa dipakai sebagai alat untuk menunjang penelitian. Hasil uji validitas yang dilakukan dengan bantuan SPSS 22.0 menghasilkan data sebagai berikut:

\begin{tabular}{|c|c|c|c|c|c|}
\hline No & Variabel & Instrumen & $\begin{array}{c}\text { Pearson } \\
\text { Correlation }\end{array}$ & $\begin{array}{c}\text { Nilai Sig. (2 } \\
\text { tailed) }\end{array}$ & Kesimpulan \\
\hline 1 & \multirow{3}{*}{ Keputusan Menjadi Wirausaha } & $K W 1$ & 0,888 & 0,000 & Valid \\
\hline 2 & & $K W 2$ & 0,818 & 0,000 & Valid \\
\hline 3 & & KW3 & 0,667 & 0,000 & Valid \\
\hline 1 & \multirow{4}{*}{ Kualitas Bawaan } & $K B 1$ & 0,816 & 0,000 & Valid \\
\hline 2 & & $K B 2$ & 0,509 & 0,000 & Valid \\
\hline 3 & & $K B 3$ & 0,709 & 0,000 & Valid \\
\hline 4 & & KB4 & 0,585 & 0,000 & Valid \\
\hline 1 & \multirow{3}{*}{ Faktor Personal dan Sosial } & FPS1 & 0,816 & 0,000 & Valid \\
\hline 2 & & FPS2 & 0,509 & 0,000 & Valid \\
\hline 3 & & FPS3 & 0,700 & 0,000 & Valid \\
\hline 1 & \multirow{5}{*}{$\begin{array}{l}\text { Hubungan Pendapatan dan } \\
\text { Karir }\end{array}$} & HPK1 & 0,575 & 0,000 & Valid \\
\hline 2 & & HPK2 & 0,524 & 0,000 & Valid \\
\hline 3 & & HPK3 & 0,487 & 0,000 & Valid \\
\hline 4 & & HPK4 & 0,515 & 0,000 & Valid \\
\hline 5 & & HPK5 & 0,722 & 0,000 & Valid \\
\hline 1 & \multirow{5}{*}{ Keterkaitan Pasar } & $K P 1$ & 0,732 & 0,000 & Valid \\
\hline 2 & & $K P 2$ & 0,798 & 0,000 & Valid \\
\hline 3 & & KP3 & 0,809 & 0,000 & Valid \\
\hline 4 & & KP4 & 0,912 & 0,000 & Valid \\
\hline 5 & & KP5 & 0,557 & 0,000 & Valid \\
\hline 1 & \multirow{3}{*}{ Keterkaitan Lingkungan } & $K L 1$ & 0,836 & 0,000 & Valid \\
\hline 2 & & $K L 2$ & 0,797 & 0,000 & Valid \\
\hline 3 & & $K L 3$ & 0,675 & 0,000 & Valid \\
\hline
\end{tabular}

Sumber: Data Primer, 2016 
Berdasarkan tabel 1. hasil uji validitas diatas dapat disimpulkan bahwa variabel keputusan menjadi wirausaha adalah valid karena tingkat signifikansi samadengan nol yaitu $\leq 0,05$. hasil uji validitas variabel kualitas bawaan $\leq 0,05$ sehingga dapat dikatakan bahwa hasilnya valid. Variabel faktor personal dan sosial juga menghasilkan nilai signifikansi $\leq 0,05$ sehingga bisa dikatakan valid. Variabel hubungan pendapatan dan karir menghasilkan angka nol yaitu $\leq 0,05$, dengan demikian hasilnya valid. Variabel keterkaitan pasar menghasilkan nilai $\leq 0,05$ sehingga disimpulkan bawa variabel ini valid. Variabel keterkaitan lingkungan juga memiliki hasil signifikansi yang sama yaitu nol atau $\leq 0,05$ sehingga variabel ini juga disimpulkan valid. Dengan demikian dapat dikatakan bahwa keseluruhann instrumen dalam variabel penelitian dikatakan valid untuk dipakai sebagai alat uji selanjutnya.

Tahapan berikutnya adalah uji reliabilitas yaitu bahwa intrumen ini secara konsisten menghasilkan data yang baik untuk dilanjutkan penelitian. Dalam uji reliabilitas ini hasilnya harus memenuhi kriteria koefisien Cronbach Alpha $\geq 0,6$. Berikut ini adalah tabel hasil uji reabilitas:

Tabel 2. Hasil Uji Realibilitas

\begin{tabular}{|c|l|c|c|}
\hline No & \multicolumn{1}{|c|}{ Variabel } & Cronbach Alpha & Keterangan \\
\hline 1 & Keputusan Menjadi Wirausaha & 0,751 & Reliabel \\
\hline 2 & Kualitas Bawaan & 0,665 & Reliabel \\
\hline 3 & Faktor Personal dan Sosial & 0,637 & Reliabel \\
\hline 4 & Hubungan Pendapatan dan Karir & 0,637 & Reliabel \\
\hline 5 & Keterkaitan Pasar & 0,666 & Reliabel \\
\hline 6 & Keterkaitan Lingkungan & 0,626 & Reliabel \\
\hline
\end{tabular}

Sumber: Data Primer, 2016

Berdasarkan kriteria koefisien Cronbach Alpha $\geq$ dari nilai kritis yang sudah ditetapkan sebesar 0,6 maka Keputusan Menjadi Wirausaha penelitian ini dikatakan reliabel. Variabel keseluruhan variabel Kualitas Bawaan dalam penelitian ini dikatakan reliabel. Variabel Faktor Personal dan Sosial dalam penelitian ini dikatakan reliabel. Variabel Hubungan Pendapatan dan Karir dalam penelitian ini dikatakan reliabel. Variabel Keterkaitan Pasar dalam penelitian ini dikatakan reliabel. variabel Keterkaitan Lingkungan dalam penelitian ini dikatakan reliabel. Untuk itu, penelitian ini dapat dilanjutkan ke tahap uji yang lainnya karena sudah menunjukkan adanya kekonsistenan jawaban responden dan teruji handal untuk dipakai penelitian.

Wirausaha adalah mereka yang menciptakan bisnis baru untuk tujuan mendapatkan keuntungan (Eijdenberg et al, 2015). Menurut Suryana (2013:53) terdapat enam ciri dari kewirausahaan yaitu percaya diri, berorientasi pada tugas dan hasil, berani menghadapi resiko, berjiwa pemimpin, keorisinalitsan, dan berorientasi pada masa depan.

Tahap berikutnya peneliti melakukan uji regresi berganda atas data responden yang sama. Analisis menggunakan regresi berganda ini menghasilkan data untuk melengkapi persamaan regresi sebagai berikut:

$$
Y=7,173+0,143 X_{1}+0,034 X_{2}+0,077 X_{3}+0,118 X_{4}-0,121 X_{5}
$$

Persamaan regresi berganda diatas dapat dilihat bahwa tergambarkan bahwa koefisien regresi untuk variabel kualitas bawaan sebesar 0,143 dapat disimpulkan bahwa variabel kualitas bawaan berpengaruh positif terhadap keputusan menjadi wirausaha. Koefisien regresi untuk variabel faktor pribadi dan sosial sejumlah 0,034 menunjukan bahwa variabel faktor pribadi dan sosial berpengaruh positif terhadap keputusan menjadi wirausaha. Koefisien regresi untuk variabel hubungan pendapatan dan karir yaitu 0,077 sehingga dapat disimpulkan bahwa variabel hubungan pendapatan dan karir berpengaruh positif terhadap keputusan menjadi wirausaha. Koefisien regresi untuk variabel keterkaitan pasar yaitu 0,118 sehingga dapat disimpulkan bahwa variabel keterkaitan pasar berpengaruh positif terhadap keputusan menjadi wirausaha. Koefisien keterkaitan 
lingkungan senilai - 0,121 sehingga dapat disimpulkan bahwa variabel keterkaitan lingkungan berpengaruh negatif terhadap keputusan menjadi wirausaha.

Pada tahapan selanjutnya peneliti menggunakan uji signifikansi individual melalui uji t yang menghasilkan nilai signifikansi untuk variabel kualitas bawaan yaitu sebesar 0,016 yaitu $\leq 0,05$ maka Ho dinyatakan ditolak dan $\mathrm{H} 1$ diterima yaitu kualitas bawaan berpengaruh positif terhadap keputusan seseorang menjadi wirausaha. Pernyataan Eijdenberg et al (2015) dan Suryana (2013) ini sejalan dengan hasil penelitian ini yaitu bahwa kualitas bawaan berpengaruh positif terhadap keputusan seseorang menjadi wirausaha. Hal ini tidak berarti bahwa untuk menjadi seorang wirausaha, seseorang harus memiliki seluruh karakter tersebut, namun dengan memiliki salah satu dari karater itu diharapkan seseorang akan memiliki modal mental yang baik untuk memulai sebuah usaha.

Variabel faktor personal dan sosial menghasilkan tingkat signifikansi sejumlah 0,581 yaitu $\geq 0,05$ sehingga mendapatkan keputusan Ho diterima dan $\mathrm{H} 1$ ditolak yaitu bahwa faktorpribadi dan sosial tidak berpengaruh positif terhadap keputusan menjadi wirausaha.Singh (2011) menjelaskan bahwa dalam hidup bermasyarakat kebutuhan seseorang tidak hanya terbatas pada kebutuhan dasar (Eijdenberg et al, 2015) namun juga kebutuhan untuk diakui. Hanya saja dalam penelitian ini menghasilkan satu temuan bahwa faktor pribadi dan sosial tidak berpengaruh positif terhadap keputusan menjadi wirausaha. Ini kaitannya dengan motivasi utama seseorang memutuskan menjadi wirausaha. Tidak semua orang motivasi utamanya adalah mendapatkan pengakuan. Faktor utama seseorang menjadi wirusaha masih pada keinginan memenuhi kebutuhan dasar bukan pengakuan.

Variabel hubungan pendapatan dan karir menghasilkan tingkat signifikansi sebesar 0,015 yaitu $\leq 0,05$ sehingga $\mathrm{Ho}$ ditolak dan $\mathrm{H} 1$ diterima yaitu bahwa hubungan pendapatan dan karir berpengaruh positif terhadap keputusan menjadi wirausaha. Pada dasarnya seseorang selalu terpacu untuk memiliki penghasilan tambahan bagi kebutuhan hidupnya (Raposo, 2008). Hal ini diperkuat oleh variabel berikutnya bahwa hubungan pendapatan dan karir berpengaruh positif terhadap keputusan menjadi wirausaha, artinya seseorang menjadi wirausaha ingin mendapatkan penghasilan lebih dan meniti karir menjadi wirausaha karena banyak orang yang akhirnya memutuskan menjadi wirausaha karena tidak ingin menganggur (Singh, 2011).

Variabel keterkaitan pasar menghasilkan tingkat signifikansi sejumlah 0,05 yaitu $\leq$ 0,05 dengan demikian Ho dinyatakan ditolak dan $\mathrm{H} 1$ dinyatakan diterima yaitu bahwa keterkaitan pasar berpengaruh positif terhadap keputusan menjadi wirausaha. Pada hasil analisis sebelumnya dinyatakan bahwa keterkaitan pasar berpengaruh positif terhadap keputusan menjadi wirausaha. Hal ini sesuai dengan teori yaitu bahwa kesempatan berwirausaha merupakan kesempatan untuk memenuhi pasar kebutuhan, minat dan keinginan, melalui kegiatan kreatif dan kombinasi sumber daya untuk memberikan nilai tambah (Eijdenberg et al, 2015). Wirausaha secara terus menerus melakukan riset pasar dan mencari jangkauan lebih luas terkait akses suplier dan pasar. Semakin mudahnya akses tersebut maka keinginan menjadi wirausaha akan semakin besar. Sumber daya yang dimaksud ini melibatkan inovasi atas ide produk atau jasa. Sebagai tambahan lagi, koneksi juga akan menambah motivasi seseorang memutuskan untuk menjadi wirausaha. Makin banyak koneksi atas bisnis yang akan dijalani akan menghasilkan semangat tertentu untuk mencapai cita-citanya membuat sebuah usaha. Mudahya akses masuk pasar dapat memotivasi seseorang untuk menekuni bisnis tertentu sehingga dia akan menjadi seorang entrepreneur (Singh, 2011). Lebih lanjut lagi bahwa akan tercipta sebuah situasi keunggulan kompetitif.

Variabel keterkaitan lingkungan mendapatkan nilai signifikansi 0,071 yaitu $\geq 0,05$ sehingga $\mathrm{Ho}$ dinyatakan diterima dan $\mathrm{H} 1$ ditolak sehingga keterkaitan lingkungan tidak berpengaruh positif terhadap keputusan seseorang menjadi wirausaha. Keterkaitan lingkungan tidak berpengaruh positif terhadap keputusan seseorang menjadi wirausaha. Hasil ini tidak mendukung penelitian sebelumnya yang dilakukan oleh Singh (2011) dan Eijdenberg et al (2015). Hal ini disebabkan oleh beberapa hal lain seperti yang diungkapkan oleh Raposo et al (2008), bahwa motivasi memiliki teori "dorong" dan "tarik" dimana dari sisi "dorong", seorang individu akan terdorong menjadi wirausaha karena kondisi ekonomi, 
ketidakpuasan terhadap pekerjaan lama, gaji tidak cukup, dan hal negatif lainnya. Kemudian dari sisi "tarik" seorang individu pun akan tertarik mencari kegiatan yang fleksibel, ingin kaya, pengakuan diri, dan hal positif lainnya.

\section{IV.Kesimpulan}

Keputusan menjadi wirausaha merupakan keputusan yang secara individu menjadi hakseseorang. Keputusan ini terdorong oleh adanya entrepreneurial motivation yang terdiri dari kualitas bawaan, faktor personal dan sosial, hubungan pendapatan dan karir, keterkaitan pasar, dan keterkaitan lingkungan. Hasilnya bahwa kualitas bawaan berpengaruh positif terhadap keputusan seseorang menjadi wirausaha. Keterkaitan pasar juga memiliki pengaruh positif terhadap keputusan menjadi wirausaha. Hanya saja ditemukan hasil bahwa keterkaitan lingkungan tidak berpengaruh positif terhadap keputusan seseorang menjadi wirausaha. Hal ini disebabkan oleh adanya teori motivasi "tarik" dan "dorong" sehingga tanpa dukungan lingkungan pun bila seseorang memang sudah berkomitmen untuk menjadi wirausaha maka dia akan mampu melakukannya. Lebih dalam lagi bahwa faktor pribadi dan sosial tidak berpengaruh positif terhadap keputusan menjadi wirausaha.Dengan demikian bahwa pengakuan bukan menjadi hal utama seseorang memutuskan untuk menjadi wirausaha. Hal ini diperkuat oleh variabel berikutnya bahwa hubungan pendapatan dan karir berpengaruh positif terhadap keputusan menjadi wirausaha, yaitu bahwa motivasi seseorang menjadi wirausaha adalah untuk mendapatkan penghasilan tambahan.

Saran untuk penelitian selanjutnya adalah membangun sebuah penelitian lanjutan untuk melihat bagaimana membangun karakter yang kuat sebagai seorang wirausaha dan membangun desain strart up business yang baik dan bertahan secara jangka panjang. Keterbatasan penelitian ini adalah lingkupnya hanya di Surabaya sehingga untuk penelitian berikutnya disarankan memasuki jangkauan yang lebih luas.

\section{Daftar Pustaka}

Bungin, Burhan. (2013). Metodologi Penelitian Kuantitatif. Jakarta: Kencana Prenada Media Group.

Chu, Hung M., Orhan K., Xiaowei Z., dan Kubilay G (2011). Chinese entrepreneurs. Journal of Chinese Entrepreneurship. 3 (2), $84-111$

Eijdenberg, Emiel L, Leonard J Paas dan Enno M. (2015). Entrepreneurial motivation and small business growth in Rwanda. Journal of Entrepreneurship in Emerging Economies. Vol. 7 Iss 3 pp. $212-240$

Industri Nasional Jelang AEC 2015. (2013). Jakarta: Majalah Industri.

Liliyah, Arie. (2015) Jumlah Wirausaha Indonesia Hanya 0,43\% dari Total Populasi. www.swa.co.id diakses tanggal 01 Januari 2016.

Loss, Monica, Bascunan. (2011). Entrepreneurship Development. India: Global Vision Publishing House

OBE, C., C. Templeman, L. (2013). Adult Enterprise: Curriculum Innovation. Assosiation of Colleges.

Peluang dan Tantangan Indonesia pada ASEAN Economic Community 2015. (2014). Jakarta: Kementrian Sekretariat Negara RI. http://www.setneg.go.id/index.php?option=com_content\&task=view\&id=7911 yang diakses 23 Januari 2015. 
Raposo, M, Arminda D. P. dan Ferreira J. (2008). Entrepreneur's Profile: A Taxonomy Of Attribu Tes And Motivations Of University Students. Journal of Small Business and Enterprise Development. 15(2), $405-418$

Sekaran, Uma dan Roger B. (2011). Research Methods for Business. United Kingdom: John Wiley \& Sons, Inc.

Singh, Satwinder, Ruth Simpson, dan Chima M.C.O. (2011). Motivation To Become An Entrepreneur: A Study Of Nigerian Women's Decisions. African Journal of Economic and Management Studies. 2 (2), $202-219$

Sugiyono. (2013). Metode Penelitian Bisnis. Bandung: Alfabeta.

Suryana. (2013). Kewirausahaan: Kiat dan Proses Menuju Sukses. Jakarta: Salemba Empat. 